\title{
The efficacy of healthy drinks based on kaempferia galanga, ginger and garlic as phytobiotics on fat content of breast, percentage of abdominal fat and broiler carcass
}

\author{
Tati Vidiana Sari ${ }^{1, *}$, Raja Indah Hamdy Harahap ${ }^{1}$, and Uswatun Hasanah ${ }^{1}$ \\ ${ }^{1}$ Lecturer of Animal Husbandry Department, Faculty of Agriculture, Universitas Sumatera Utara, Dr. \\ A. Sofian District No. 3, Medan 20155, North Sumatera, Indonesia \\ ${ }^{2}$ Student of Animal Husbandry Department, Faculty of Agriculture, Universitas Sumatera Utara, Dr. \\ A. Sofian District No. 3, Medan 20155, Sumatera Utara, Indonesia
}

\begin{abstract}
This study aimed to examine the effect of giving healthy drinks based on Kaempferia galanga, ginger and garlic on broiler rearing on the level of breast fat, percentage of abdominal fat and carcass. This research used a CRD with 7 treatments and 3 replications. The concentration of active ingredient in water solution treatment is $1.06 \% / \mathrm{L}$. The result showed that the giving of healthy drinks giving a very significant difference $(\mathrm{P}<0.01)$ on all parameters research. The result of DMRT test showed that the M2 treatment had fat content $58,96 \%$ which was significantly higher than M6(47.52\%), M0(39.24\%) and M1(34.65\%) while the fat content in M3(32.21\%), M4(33.31\%) and M5(27.51\%) were significantly lower than other treatments. The value of the percentage of abdominal fat at M0 $(2,28 \%)$ was very significantly the highest compared to other treatments and each treatments also gave very significant difference $(\mathrm{P}<0.01)$ results. The percentage of broiler carcasses in the M5(83.42\%) gave a very significantly higher, while the M0(73,24\%) gave a significantly lower than the other treatments. It can be concluded that the best healthy drink was given in the M5 treatments because it produced the lowest fat content and the highest carcass percentage of broiler meat.
\end{abstract}

\section{Introduction}

Traditional medicinal ingredients made from natural plants have been used for generations to maintain body health and treat several types of disease. This tradtional herb in Indonesia is known as herb medicine [1]. Currently, herb medicine is not only used for humans, but has also begun to be used by poultry farmers. Medicinal plants that can be used as solution in livestock are called phytobiotics [2]. The breeders use several medicinal plants to

\footnotetext{
* Corresponding author: tati.vidiana@usu.ac.id
} 
become traditional medicines for their livestock as a substitute for factory-made medicines which are considered quite expensive, especially for middle to lower scale farmers [3].

The potential of medicinal plants in the field af animal health is still being developed because it contains many bioactive compounds. Among them are Kaempferia galanga, ginger and garlic. Kaempferia galanga is usually used as cooking spice and is widely used in traditional medicinal herbs. Kaempferia galanga can provide body warmth, pain relief and also an appetite enhancer [4]. Almost all parts of the Kaempferia galanga plant contain essential oils, where the largest component the essential oil is ethyl-p-methoxy cinnamate $\left(\mathrm{C}_{12} \mathrm{H}_{14} \mathrm{O}_{3}\right)$ [5], while the component is the main identity of Kaempferia galanga [6]. Ginger contains the active substance gingerone which functions to slow down intestinal peristaltic so as to make the absorption process of feed nutrients in the small intestine optimal [7] and flavonoid, pheno, and terpenoid compounds [8]. Ginger also has antioxidant with the content of gingerol, shogaol and gingerone has higher antioxidant power than vitamin E. The essential oil content in ginger is $2.49 \%$ and the gingerol content is $0.799 \%$ [9]. Garlic content allicin which function as antimicrobial and antibacterial [10] and has full strenght as an anti bacterial compared to other types of antibiotics [11] and several other functions of medicinal plants which are very useful for maintaining health and are believed to have no harmfull side effects [12].

Broiler is one type of chicken that is kept by many breeders in Indonesia that is easy to maintain, its fastest growth, its meat is very well liked by consumers, and the price is affordable by people's purchasing power. However, the amount of fat contained in the broiler body in addition to its fat content is one of the reasons consumers with a healthy lifestyle do not want to consume broiler meat. The meat content of broiler meat varied from : $2.5 \%$ [13] and $19 \%$ [14] while the percentage of abdominal fat ranged from $2.38-3.09 \%$ [15] and $0.73-3.86 \%$ of body weight [16].

Increased consumer awareness for a healthy lifestyle has led to an increasingly popular trend for healthy food. Insluding animal products that have high protein content. The use of a combination of various medicinal plants in the broiler rearing process is expected to improve the quality of meat products, including producing meat with low fat content and safe for consumption. By utilizing several types of medicinal plants. It will also help protect the environment around the farm site from antibiotic residues that are often used by farmers to maintain the productivity of their livestock so it is safe for sustainable environtment.

\section{Materials and methods}

\subsection{Time and Research Place}

This research was conducted from July to August 2021 at the Farm House in Kapten Muslim Street of Medan City and Laboratory of Food Biochemistry in Faculty of Mathematics and Natural Sciences, Universitas Sumatera Utara.

\subsection{Materials and tools}

The material used are day old chick strain cobb CP 707 unsex, a commercial feed, healthy drink with Kaempferia galanga, ginger, garlic, shallot, betel leaf, turmeric, Curcuma zanthorrhiza, Alpinia galanga, lemonggrass and coriander combination according to treatment and meat from broiler chickens harvested at the 35 days old and meat of broiler breast. The tool use are cage, food container, drink holder, harvesting equipment andsoxhlet 
extraction tools. The research in this study were 7 with 3 replications, so that as a whole produced twenty one samples of broiler meat.

\subsection{Research methods}

This research used was an experimental design were analyzed with completely randomize design (7 treatmens and 3 replications). Duncan's Multiple Range test (DMRT) was used for multiple comparisons to identify significant differences between means $(\mathrm{P}, 0.05)$.

\subsection{Research parameters and sampling}

After maintenance for 35 days, 21 unsex of broiler were randomly chosen from 105 broiler were wighed, brought to the slaughterhouse. After completing the slaughtering process, the digestive tract and internal organs such as liver, heart, gall bladder and pancreas were separated and weight on 0,01 digital scale and than test parameters and methods are as follows:

\subsubsection{Fat content of breast}

Breast fat content analyzed using the soxhlet extraction method by AOAC [17].

\subsubsection{Abdominal fat percentage}

Abdominal fat percentage measurement done by weighing fat obtained from fat that is in the arround the gizzard and the adhesive layer between the abdominal and intestinal muscles an then weighed. Abdominal fat percentage was obtained by comparing abdominal fat weight with live weight multiplied by 100 [18].

\subsubsection{Carcass percentage}

Carcass percentage obtained by comparing the weight of the broiler body without fur, blood, head, neck, legs and internal organs in (grams) with live weight (grams) multiplied by $100 \%$

\subsection{How to make a healthy drinks}

The healthy drinks used are Kaempferia galanga, ginger, garlic with cobination of: betel leaf, turmeric, shallot, Curcuma zanthorrhiza, Alpinia galanga, lemonggrass and coriander. Then the herbs is trimmed, blended, and boiled to an endpoint temperature of $95^{\circ} \mathrm{C}$. The boiled herbs solution is filtered and stored. It can be stored at room temperature for up to 2 days and 5 days at refrigerator temperature. The concentration of active ingredients in each liter of drinking water treatment is $1.06 \% / \mathrm{L}$ with the use of $25 \%$ of the daily drinking water needs of broilers for 4 weeks.

\section{Results and discussion}

The result of breast fat, abdominal fat percentage and carcass percentage with addition of: M0 (control), M1 (garlic); M2 (shallot and garlic); M3 (Kaempferia galanga and garlic); M4 (ginger and garlic); M5 (Kaempferia galanga, ginger, garlic with combination of turmeric and betel leaf); and K6 (Kaempferia galanga, ginger, garlic with combination of 
turmeric, shallot, Curcuma zanthorrhiza, betel leaf, Alpinia galanga, lemongrass and coriander) were presented in Table 1 . The result show that all the treatment give a very significant difference $(\mathrm{P}<0.01)$ on all observation parameters.

\subsection{Fat content}

The average value of the fat content (\%) in this reasearch were respectively $39.24 \%$ (M0), 34.65\% (M1), 58.95\% (M2), 32.21\% (M3), 33.31\% (M4), 27.\%1\% (M5) and 47.52\% (M6). Based on the analysis variance, it showed that the giving of healthy drinks had a very significant difference $(\mathrm{P}<0.01)$ on the fat content of breast broiler. The value of fat content was very high, exceeding the fat content of broilers in general namely $19 \%$ [14]. This probably due to the high fat content in the commercial diet which reaches $55,75 \%$ according the result of Laboratory of Food Biochemistry in Faculty of Mathematics and Natural Sciences, USU [19]. High feed fat in the commercial feed can cause fat accumulation in the broiler meat that consumes it. In line with opinion Amrullah [20], states that trygliserides are the main fat stored in chicken body tissues. About $95 \%$ of trygliserides come from the diet while the remaining $5 \%$ is synthesized in the body. Fat from food is stored in fat cells in the form of lippoproteins, therefore ration fat becomes a determining factor for fat. These fats can leave fat cells to enter the blood system and be transported to other parts if demands increase, but excess fat can never be removed from the body.

Table 1 . The effect of healthy drinks on breast fat, abdominal fat percentage and carcass percentage value.

\begin{tabular}{|c|c|c|c|}
\hline \multirow{2}{*}{ Treatment } & \multicolumn{3}{|c|}{ Average Value of } \\
\cline { 2 - 4 } & $\begin{array}{c}\text { Breast Fat Content } \\
(\%)\end{array}$ & $\begin{array}{c}\text { Abdominal Fat } \\
\text { Percentage (\%) }\end{array}$ & Carcass Percentage (\%) \\
\hline M0 & $39.24 \pm 46.70^{\mathrm{C}}$ & $2.28 \pm 0.011^{\mathrm{A}}$ & $72.23 \pm 1.60^{\mathrm{E}}$ \\
\hline M1 & $34.65 \pm 14.06^{\mathrm{C}}$ & $0.29 \pm 0.016^{\mathrm{G}}$ & $80.39 \pm 10.17^{\mathrm{B}}$ \\
\hline M2 & $58.96 \pm 79.08^{\mathrm{A}}$ & $0.95 \pm 0.013^{\mathrm{D}}$ & $75.83 \pm 3.16^{\mathrm{D}}$ \\
\hline M3 & $32.21 \pm 2.37^{\mathrm{D}}$ & $1.27 \pm 0.007^{\mathrm{C}}$ & $77.44 \pm 3.16^{\mathrm{C}}$ \\
M4 & $33.31 \pm 10.39^{\mathrm{D}}$ & $0.91 \pm 0.023^{\mathrm{E}}$ & $76.28 \pm 1.10^{\mathrm{C}}$ \\
M5 & $27.51 \pm 3.45^{\mathrm{D}}$ & $0.73 \pm 0.001^{\mathrm{F}}$ & $83.42 \pm 3.80^{\mathrm{A}}$ \\
M6 & $47.52 \pm 74.36^{\mathrm{B}}$ & $1.30 \pm 0.012^{\mathrm{B}}$ & $77.11 \pm 0.16^{\mathrm{C}}$ \\
\hline
\end{tabular}

Note : $\mathrm{A}, \mathrm{B}, \mathrm{C}, \mathrm{D}, \mathrm{E}, \mathrm{F}, \mathrm{G}=$ Different letter notations on the same column show that high significantly different at the $1 \%$ level according to the DMRT test

The result of DMRT show that the breast fat content of broiler in M2 (shallot and garlic) treatment was significantly higher that other treatmens exceeds the control (M0) and in M3 (Kaempferia galanga and garlic), M4 (ginger and garlic) and M5 (Kaempferia galanga, ginger, garlic with combination of turmeric and betel leaf) was significantly lower. When compared with the control, the treatment on M3, M4 and M5 was significantly able to reduce broiler breast fat levels at the time of observation. This shows that the reaction of the active substance with the use of herb lants is different. The use of garlic in solution was not significantly able to reduce fat content compared to controls, but when its use was combined with Kaempferia galanga, ginger, turmeric and betel leaf, the results were very significant in reducing the fat content meat. 
The use of garlic should have been able to reduce the fat content of meat significantly compared to the control, but it is suspected that the active substance in garlic has been damaged in the boiling process at the time of making the solution so that the substance is not very effective in reducing body fat. The level of allin compounds and other organo-sulfur compounds are influenced by variety, processing method, level of compound stability, and the length of time the material is stored. The active compound Alliin in garlic has unstable properties and is relatively difficult to absorb from the small intestine wall, so this compound is easily damaged during processing. Volatile sulfur compounds such as Allicin. Allicin is a less stable compound, under the influence of hot water, air oxygen, and an alkaline environment, it is easily decomposed into other sulfur compounds such as diallyl sulfide [21]. Generally, the effect of garlic on lowering fat and cholesterol in chickens is related to the inhibition of the function on main enzymes involved in fat and cholesterol synthesis [22], so that garlic supplementation affects on fat and cholesterol [23].

\subsection{Abdominal fat percentage}

The abdominal fat percentage value of broiler breast on this study presented in Table 1 . The average from the treatment were respectively $2.28 \%$ (M0), $0.29 \%(\mathrm{M} 1), 0.95 \%(\mathrm{M} 2)$, $1.27 \%$ (M3), $0.92 \%$ (M4), $0.73 \%$ (M5) and 1.30 (M6). This result is still the range of the results of previous studies from 0.73 to $3.86 \%$ of live weight [16]. One of the problems in raising broiler in Indonesia is a very high environmental temperatur at dry season. Heat stress will make broiler less moving so as to produce abdominal fat deposits due to broiler use more energy as trying to stay comfortable [24]. The ambient temperature high can indrease fat content body, while the carcass weight and carcass parts were maintained at is having a bigger weight compared to maintenance on high temperature [25]. This is in accordance with the temperature conditions at the time of maintenance which have an average of $36^{\circ} \mathrm{C}$.

The results of analysis variance showed that the giving of healthy drinks had a very significant difference $(\mathrm{P}<0.01)$ in reducing the abdominal fat percentage of broiler. The result of DMRT show that the abdominal fat percentage of broiler as a control (M0) had a very significantly higher value, and the M1 treatment gave different results, which was significantly lower than the orthers. This is in contrast to the fat content, where the fat content of control (M0) was not significantly different from the garlic (M1). This shows that the giving of garlic solution has actually been able to reduce the fat content in the broiler body but has not reached the optimal level with the doses and concentrations given during the study.

Fat accumulation is influenced by the composition of the feed, including the energy level in the feed, the ratio of protein energy and the fat content of the feed. The fat content in the feed will affect the fat cummulation of broilers [26]. Abdominal fat and carcas fat had a positive correlation, that is, if abdominal fat increased, carcass fat would also increase [27] deposition of broiler fat is generally stored in the form of in abdominal cavity and under the skin [28]. But this is contrary to the results of this study, where the highest fat content (Table 1) was in the M2 treatment (shallot and garlic solution) but the highest percentage of abdominal fat was in control treatmen (M0). This is presumably because broilers control don't have active substances that can convert abdominal fat into meat so that the fat is pilled up around the abdominal, buttocks and neck. While broilers that get the 
healthy drinks with medicinal plants have the ability to transport feed fat into the blood circulation and then stored in the muscles. Energy from most of the fat in the body is stored in fat depots called intramuscular which are located in the perimyceal connective tissue and are often called to as marbling fat [13]. The active substance in healthy drink containing garlic are able to reduce levels of blood serum cholesterol [22], blood serum triglyceride levels [29] and blood plasma cholesterol and fat levels as well as reduce the cholesterol and fat content of breast meat and thigh [23].

\subsection{Carcass percentage}

The average percentage of broiler carcasses at 5 weeks with the addition of healthy drinks varied from $73.24 \%$ (M0) to $83.42 \%$. The results of the analysis showed that the addition of healthy drinks had a very significant difference $(\mathrm{P}<0.01)$ to increasing the carcass percentage of broiler. From this study, the average carcass percentage of broiler was higher than the results of Leeson and Summers [30] study that is equal to $64.7 \%-71.2 \%$ and according to Siregar [31], that the percentage of carcass 5 week old broiler between 65 $75 \%$.

DMRT test result show that the carcass percentage of broiler on M0 was very significant difference $(\mathrm{P}<0.01)$ lower and the value on $\mathrm{M} 5$ was very significant difference higher than the others. The material active of medicinal plants are able to inhibit growth (inhibitory activity) against food borne pathogens, fungi, and pathogens in the digestive tract [32], increase the digestibility ob substances food [33], so as to increase the value of carcass percentage.

\section{Conclusion}

The conclusion of this study is the giving of healthy drink on broiler drinking water showed a very siginificant difference $(\mathrm{P}<0.01)$ to all parameters research. It can be concluded that the best healthy drink was given in the M5 treatments (Kaempferia galanga, ginger, garlic with combination of turmeric and betel leaf) because it produced the lowest fat content and the highest carcass percentage of broiler meat.

\section{Reference}

1. Marni, Khasiat jamu cekok terhadap penyembuhan diare pada anak pada Prosiding Seminar Nasional Dan Call For Papers UNIBA pp 25-31(2014)

2. L.W. Hidayat, Pengaruh penambahan campuran fitobiotik, acidifier, dan probiotik bentuk non enkapsulasi dan enkapsulasi dalam aditif pakan terhadap karakteristik usus itik pedaging (Sarjana Thesis Universitas Brawijaya, Malang, 2015)

3. H. Sudirman, J. Agrisistem, 8, 49-56 (2012)

4. S. Kusumaningati, Kaempferia galanga L dalam ransum jamu [Kaempferia galanga in Herbs Rations] Prosiding Seminar Nasional VI Tumbuhan Obat Indonesia Bandung (1994)

5. A. Subroto, Pembuatan Bubuk Konsentrat Kencur (Kaempferia galanga L.) (Fakultas Teknologi Pertanian IPB, Bogor, 1987)

6. S. Pranomo, Etil-p-metoksi sinamat dan Kaempferia Zat Identitas Rimbang Kencur (Kaempferia galanga L) Prosiding Seminar Nasional VI Tumbuhan Obat Indonesia Bandung (1994) 
7. Harmono, Andoko, Budi Daya dan Peluang Bisnis Jahe (Agromedia Pustaka, Jakarta, 2005)

8. W.S. Nursal, W.S. Juwit, J. of Biogenesis 2, 64-66 (2006)

9. L. Agustina, Penggunaan ramuan herbal sebagai feed additive untuk meningkatkan performans broiler Prosiding Lokakarya Nasional Inovasi Teknologi dalam Mendukung Usaha Ternak Unggas Berdaya Saing Pusat Penelitian dan Pengembangan Peternakan pp 47-52 (2006)

10. J. Salima, Med. J. of Lampung University, 4, 30-39 (2015)

11. R.M. Ismail, A.H.A. Saleh, K.S. Ali, J. of Medicinal Plants Studies, 8, 26-30 (2020)

12. N. Fitriyah, P.K. Mahendra, M.A. Alfiyanto, Mulyadi, N. Wahyuningsih, J. Kismanto, J. Kesehatan Kusuma Husada, 4, 116-122 (2013)

13. Soeparno, Ilmu dan Teknologi Daging 4th ed (Gajah Mada University Press, Yogyakarta, 2009)

14. F.G. Winarno, F. Srikandi, D.Fardiaz, Pengantar Teknologi Pangan (Gramedia, Jakarta, 1982)

15. R.R. Apritar, Optimalisasi penggunaan kombinasi dan interval pemberian ramuan herbal cair terhadap presentase karkas dan lemak abdominal broiler (Laporan Penelitian Fakultas Pertanian Universitas Hasanuddin, Makassar, 2012)

16. W.A. Becker, J.V. Spencer, L.W. Minishand, J.A. Werstate, Poult. Sci., 60, 692-697 (1979)

17. AOAC, Official Methods of Analysis 16th ed (AOAC International, Washington DC, 1999)

18. Witantra, Pengaruh pemberian lisin dan metionin terhadap persentase karkas dan lemak abdominal pada ayam pedaging asal induk bibit muda dan induk bibit tua (Artikel Ilmiah Universitas Airlangga, Surabaya, 2011)

19. Laboratory of Food Biochemistry, Hasil Analisis Pakan (FMIPA USU, Medan, 2021)

20. K.L. Amrullah, Nutrisi Ayam Broiler (Lembaga Satu Gunungbudi, Bogor, 2002)

21. H. Amagase, B.L. Petesch, H. Matsuura, S. Kasuga, Y. Itakura, The Journal of Nutrition, 131, 955S-962S (2001)

22. A.A. Qureshi, Z.Z. Din, N. Abuirmeileh, W.C. Burger, Y. Ahmad, C.E. Elson, J. Nut., 113, 1746-1755 (1983)

23. V.H. Konjufca, G.M. Pesti, R.I. Bakalli, Poult. Sci., 76, 1264-1271 (1997)

24. A. Chawalibag, B.O. Eggum, Arch. Geflgelked, 53, 179-184 (1989)

25. M.O. Smith, Poult. Sci., 72, 1146-1150 (1993)

26. S.S. Maryuni, C.H. Wibowo, J. Indon. Trop. Anim. Agric. 30 (1) pp $26-33$ (2005)

27. L.D. Mahfudz, F.L. Maulana, U. Atmomarsono, T.A. Sarjana, Karkas dan lemak abdominal ayam broiler yang diberi ampas bir dalam ransum pada Prosiding Seminar Kebangkitan Peternakan Pemberdayaan Peternakan Berbasis Sumber Daya Lokal untuk Ketahanan Pangan Berkelanjutan Pp. 596-605 (2009)

28. D. Meliandasari, B. Dwiloka, D. Suprijatna, J. Aplikasi Teknologi Pangan, 4, 22-28 (2015)

29. S. H. Dehkordi, A. Z. Moghadam, N. Maghsoudi, N. Aali, R. Gerami, E. Dehsadeghi, Comp. Clin. Pathol., 19, 363-365 (2010)

30. S. Leeson, J.D. Summers, Commercial Poultry Nutrition 2nd Edition (University Books, Canada, 1997)

31. A. Siregar, P.M. Sabrani, P. Suprawiro, Teknik Beternak Ayam Pedaging di Indonesia (Margie Group, Jakarta, 1980)

32. I.A.K. Bintang, A.G. Nataamijaya, Pengaruh penambahan tepung kencur (Kaempferia galanga L) dan tepung bawang putih (Allium sativum L) ke dalam pakan terhadap performan broilers (Laporan Penelitian Balai Penelitian Ternak, Bogor, 2004) 
33. M. Ulfah, Influence of essential oils on the performance data and health condition of monogastric animals (Thesis Agricultural Faculty, George August University Göttingen, Germany, 2003) 